\title{
UJI AKTIVITAS ANTI DIABETES MELLITUS SENYAWA METABOLIT SEKUNDER FRAKSI AIR DARI BERAS KETAN HITAM ( Oryza satival. Var glutinosa) PADA MENCIT PUTIH
}

\author{
Iryani $^{1 *}$, Iswendi ${ }^{1}$, Indria Trisna Katrina ${ }^{2}$ \\ ${ }^{1}$ Jurusan kimia, Universitas Negeri Padang, Sumatera Barat, Indonesia \\ ${ }^{2}$ Program Studi Kimia, Universitas Negeri Padang, Sumatera Barat, Indonesia \\ *email : in.iryani@yahoo.co.id,wenthabrani@gmail.com.,indria_trisna@yahoo.com
}

\begin{abstract}
Diabetes mellitus is a disorder of carbohydrates, fats and proteins metabolism which are shown by hyperglycemia due to a decrease of insulin secretion and sensitivity. diabetes treatment can be done medically and traditionally. People often use the water of boiled plant mangosteen rind, jengkol rind and black sticky rice traditionally. A research of anti diabetes mellitus water fraction activities test of black sticky rice was done to determine the proper dose of the water fraction of black sticky rice to decline blood glucose levels of diabetic mice. Blood glucose levels were determined by glucose tolerance method using an instrument called NESCO Multicheck Glukosa ${ }^{\circledR}$. Dose Variations used was 125 $\mathrm{mg} / \mathrm{kg}, 250 \mathrm{mg} / \mathrm{kg}, 500 \mathrm{mg} / \mathrm{kg}$ of body weight and treatment times are 60, 90, 120, and 150 minutes. Research data were analyzed statisticaly by SPSS using analysis of variance (ANOVA) method and Duncan's multiple range test. The result showed that the water fraction of black sticky rice can decrease blood glucose levels of white mice. The value of Fcalculated > Ftable which are 14.55 and 6.09 respectively. Water fraction dosage which cause a highest decrease of glucose levels was $500 \mathrm{mg} / \mathrm{kg}$ of body weight.
\end{abstract}

\section{Keywords : Diabetes Mellitus, black stickys rice, water fraction}

\section{Pendahuluan}

Seiring dengan perkembangan zaman dan teknologi, banyak terjadi perubahan yang signifikan pada kehidupan manusia termasuk di Indonesia, terutama dalam memilih gaya hidup dan salah satunya adalah makanan. Saat ini makanan banyak menjadi penyebab penyakit penyakit yang tergolong sangat sulit untuk disembuhkan, salah satunya adalah diabetes mellitus. Penderita diabetes di Indonesia pada tahun 2015 sekitar 9,1 juta jiwa (ikatan dokter anak Indonesia, 2015). Diabetes menyebar lebih cepat di Asia.Tahun 2025 penderita diabetes diperkirakan akan mencapai 170 juta jiwa. 100 juta penderita berasal dari India dan RRC (Sustrani et al 2006).

Penyakit diabetes mellitus (DM) merupakan penyakitkronis gangguan metabolisme karbohidrat, lemak dan protein yang di tandai dengan tingginya kadar gula darah. Hal ini disebabkan oleh penurunan 
sensitivitas dan sekresi insulin, sehingga menyebabkan komplikasi kronis mikrovaskuler, makrovaskuler, dan neuropati (sowers.2001, Yuliana elin.2009).

Diabetes Mellitus terdiri dari beberapa jenis yaitu Diabetes Mellitus Tipe I, Diabetes Mellitus Tipe II, Diabetes Mellitus Tipe Gestasional, dan Diabetes Mellitus Tipe Lainnya. Jenis Diabetes Mellitus yang paling banyak diderita adalah Diabetes Mellitus Tipe 2. Diabetes Mellitus Tipe 2 (DM Tipe 2) adalah penyakit gangguan metabolik yang di tandai oleh kenaikan gulah darah akibat penurunan sekresi insulin oleh sel beta pankreas dan atau ganguan fungsi insulin (resistensi insulin

Diabetes mellitus (DM) tipe II dapat terjadi akibat konsumsi karbohidrat yang berlebih sehingga tubuh beresiko mengabsorpsi glukosa lebih banyak dari biasanya dan terjadi kondisi hiperglikemia, Bila hiperglikemia berlangsung secara terusmenerus(kronis), maka dapat timbul sejumlah komplikasi seperti retinopati (penyakit mata akibat penebalan membran basal kapiler), nefropati (berpotensi menimbulkan gagal ginjal) dan neuropati (berpotensi menimbulkan disfungsi kandung kemih dan impotensi). (mustofa.2012)

Diabetes Mellitus biasa disebut dengan the silent killer karena penyakit ini dapat mengenai semua organ tubuh dan menimbulkan berbagai macam keluhan. Penyakit yang akan ditimbulkan antara lain gangguan penglihatan mata, katarak, penyakit jantung, sakit ginjal, impotensi seksual, luka sulit sembuh dan membusuk/gangren, infeksi paruparu, gangguan pembuluh darah, stroke dan sebagainya. Tidak jarang, penderita DM yang sudah parah menjalani amputasi anggota tubuh karena terjadi pembusukan. (kurnia.2013)

kadar glukosa darah dipengaruhi oleh faktor endogen dan eksogen. Faktor endogen yaitu humoral factor seperti hormon insulin, glukagon dan kortisol sebagai sistem reseptor di otot dan sel hati. Faktor eksogen antara lain jenis dan jumlah makanan yang dikonsumsi serta aktivitas yang dilakukan. (devi.2013)

Diabetes didalam dunia kedokteran dapat diatasi dengan mengggunakan obat, baik secara oral atau dengan injeksi ke dalam pembuluh darah. Inhibitor enzim $\alpha$ glukosidase (IAG) merupakan salah satu obat bagi penderita diabetes mellitus yang diberikan secara oral. Obat ini membantu tubuh mengabsorpsi gula lebih lambat dengan menghambat kerja enzim $\alpha$-glukosidase pada sel usus halus sehingga gula darah tidak meningkat. Obat ini harus dimakan setiap kali penderita mengkonsumsi makanan terutama karbohidrat. Ada dua tipe IAG dengan prinsip kerja yang sama yaitu accarbosee (merek dagang Precose) dan miglitol (merek dagang Glyset). Penggunaan obat sintesis memiliki kelemahan yaitu adanya efek samping pada lambung (Neal, 2002). Obat diabetes yang diberikan secara oral selain jenis IAG ini adalah glibenclamid yang mampu merangsang sekresi insulin sehingga dapat menurunkan kadar glukosa. (rahayuningsih. 2015)

Masyarakat pada umumnya banyak menggunakan tanaman dalam pengobatan diabetes ini, seperti rebusan kulit manggis, kulit jengkol, bawang dayak dan beras ketan hitam. Penggunaan tumbuhan sebagai obat sangat erat kaitannya dengan kandungan kimia yang terdapat dalam tumbuhan tersebut, terutama zat aktif biologisnya. Senyawa bioaktif yang terdapat dalam tumbuhtumbuhan biasanya merupakan senyawa metabolit sekunder seperti flavonoid, alkaloid, steroid, saponin, terpenoid, tannin, dan lainlain (Kusuma, 1988)

Saat ini beberapa tanaman di Indonesia telah digunakan sebagai obat diabetes mellitus dan telah diteliti secara ilmiah, antara lain sambiloto (Andrographis paniculata Ness), johar (Cassia siamea Lamk), dandang gendis (Clinicanthus nutans Lindau), bawang putih 
(Allium sativum L.) dan cecendet (Physalis minima L.) (Gustina, 2012).

Beras ketan hitam merupakan salah satu jenis beras yang mengandung senyawa metabolit sekunder seperti : alkaloid,flavonoid, tannin dan steroid (agus, 2016). Beras ketan hitam mempunyai efek menguntungkan bagi tubuh seperti perlindungan terhadap penyakit kardiovaskuler, diabetes mellitus, anti inflammasi, anti kanker dan antioksidan. Flavonoid dalam beras ketan hitam ini dapat digunakan untuk menurunkan kadar glukosa darah, yaitu dengan menghambat kerja enzim $\alpha$-glukokinase yang terdapat di usus halus. (Brahmachari,2011).

Flavoniod merupakan senyawa yang bersifat polar yang memiliki gugus hidroksil yang terdistribusi sehingga pelarut air dan etanol dapat digunakan untuk mengekstrak flavonoid (rahayuningsih. 2014)

.Pada penelitian ini digunakan ekstrak beras ketan hitam yang di injeksikan ke mencit karena beras ketan hitam ini mengandung flavonoid dan diperkirakan mampu menurunkan kadar glukosa darah.

\section{Beras Ketan Hitam}

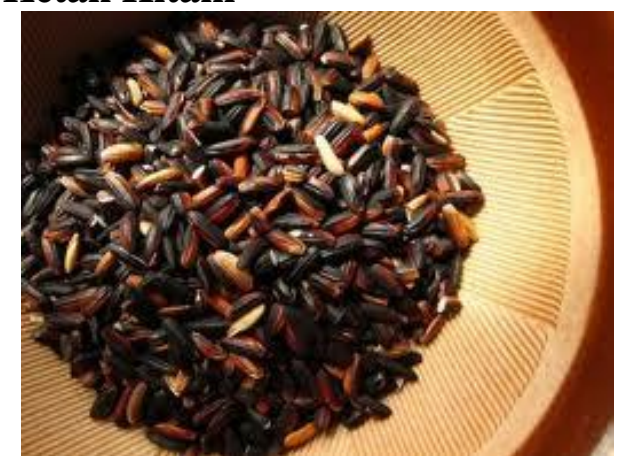

Gambar 1. Beras Ketan Hitam

\section{METODE PENELITIAN}

\section{A. Bahan Penelitian}

Bahan yang digunakan adalah beras ketan hitam (Oriza sativa l. var glutinosa). Bahan kimia yang digunakan adalah nheksana, etil asetat, glibenclamid, $\mathrm{HCl}$ pekat, aquadest, larutan glukosa $50 \%, \mathrm{NaCMC} 1 \%$, serbuk $\mathrm{Mg}$ dan fraksi air beras ketan hitam.

\section{B. Alat}

Peralatan yang digunakan pada penelitian ini meliputi peralatan gelas, neraca analitik, jarum gevage, kandang mencit, timbangan hewan, rotary evaporator vacuum, satu set alat fraksinasi, dan alat ukur kadar gula darah NESCO Multicheck glucose®.

\section{Hewan Percobaan}

Hewan percobaan yang digunakan adalah mencit putih (Mus Musculus) jantan yang berumur 2 - 3 bulan dengan berat badan 25 30 gram.

\section{Prosedur Kerja}

\section{Isolasi ekstrak berair dari beras ketan hitam}

\section{a) Ekstraksi}

Satu kg Sampel yang sudah disediakan kemudian dimaserasi dengan methanol

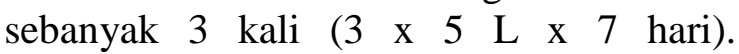
Selanjutnya disaring dan diuapkan pelarutnya dengan rotary evaporator sehingga diperoleh ekstrak metanol kental. Ekstrak kental tersebut ditambahkan air panas (suhu $50^{\circ} \mathrm{C}$ ) sebanyak $110 \mathrm{~mL}$, kemudian disaring sehingga didapat ekstrak berair.

\section{b) Fraksinasi}

Ekstrak berair difraksinasi dengan $\mathrm{n}$ heksana menggunakan corong pisah sehingga diperoleh fraksi berair $(\mathrm{Mg}-\mathrm{HCl}$ (+)) dan fraksi n-heksana ( $\mathrm{Mg}-\mathrm{HCl}(-))$. Fraksi berair difraksinasi lagi dengan etil asetat, sehingga diperoleh fraksi etil asetat dan fraksi air. Fraksi etil asetat dan fraksi air diuji dengan shinoda test. Fraksi air yang diperoleh kemudian dipekatkan dengan alat rotary evarator vacuum, sehingga diperoleh ekstrak kental.

\section{Pembuatan Reagen}

a) Reagen $\mathrm{NaCMC} 1 \%$ 
NaCMC ditimbang sebanyak 0,1 gram,kemudian digerus di dalam lumping dan ditambahkan air panas sebanyak $1 \mathrm{~mL}$ .,biarkan beberapa menit, kemudian digerus kembali sampai homogen. Selanjutnya tambahkan aquadest, masukkan ke dalam labu ukur $10 \mathrm{~mL}$ dan tambahkan aquadest sampai tan da batas.

\section{b) Larutan Glukosa $10 \%$}

Glukosa ditimbang sebanyak 1 gram, kemudian dilarutkan dengan aquadest dalam gelas kimia. Dimasukkan ke dalam labu ukur $10 \mathrm{~mL}$ dan ditambahkan aquadest sampai tanda batas, diaduk hingga homogen.

\section{c) Suspensi Glibenclamid dalam NaCMC 1} $\%$

Glibenclamid sebanyak $5 \mathrm{mg}$ digerus halus, kemudian disuspensikan dengan NaCMC $1 \%$ sebanyak $1 \mathrm{~mL}$, digerus sampai homogen. Kemudian dimasukkan kedalam labu ukur $50 \mathrm{~mL}$. Lalu tambahkan NaCMC $1 \%$ sampai tanda batas, diaduk hingga homogen.

\section{Penentuan Dosis}

a) Dosis sampel yang diberikan pada mencit ditetapkan berdasarkan evaluasi keamanan ekstrak berair, studi toksisitas pada mencit.

Variasi dosis fraksi air yang diberikan untuk mencit sebagai berikut.

1) Dosis I adalah $125 \mathrm{mg} / \mathrm{kg}$ BB.

2) Dosis II adalah $250 \mathrm{mg} / \mathrm{kg} \mathrm{BB}$.

3) Dosis III adalah $500 \mathrm{mg} / \mathrm{kg} \mathrm{BB}$.

b) Dosis glibenclamid yang digunakan adalah $0,65 \mathrm{mg} / \mathrm{kg}$ BB mencit.

\section{Uji antidiabetes}

Pengujian efek antidiabetes ekstrak berair beras ketan hitam dilakukan dengan metode toleransi glukosa. Parameter yang diamati adalah kadar eksrak berair yang digunakan dan lama waktu perlakuan. Hewan percobaan (mencit) yang digunakan berjumlah 15 ekor dikelompokkan menjadi lima kelompok. Kelompok A merupakan kelompok kontrol negatif, kelompok B merupakan kelompok pembanding (kontrol positif), sedangkan kelompok C, D dan E adalah kelompok perlakuan. Masing-masing kelompok terdiri dari dua ekor mencit yang telah dipuasakan selama \pm 18 jam. Hewan percobaan diberikan larutan glukosa 50\% secara oral setengah jam setelah pemberian sediaan uji.

Aktivitas antidiabetes dari bahan uji dapat dilihat dari parameter penurunan kadar glukosa darah pada mencit diabetes yang dibandingkan terhadap kelompok kontrol. Pengukuran kadar glukosa dilakukan sebelum perlakuan, dan satu jam setelah pemberian bahan uji pada menit ke- 60, 90, 120, dan 150 . Sebelum dilakukan perlakuan berat hewan percobaan ditimbang.

1. Kelompok A sebagai kelompok kontrol negatif diberikan larutan $\mathrm{NaCMC} 1 \%$.

2. Kelompok B sebagai kelompok pembanding (kontrol positif) diberikan suspensi glibenclamid dalam NaCMC $1 \%$ dengan dosis $0.65 \mathrm{mg} / \mathrm{g} \mathrm{BB}$ mencit.

3. Kelompok C, D dan E merupakan kelompok perlakuan yang diberi suspensi fraksi air beras ketan hitam dalam NaCMC $1 \%$ dengan dosis $125 ; 250$ dan $500 \mathrm{mg} / \mathrm{kg} \mathrm{BB}$. Tiga puluh menit kemudian, masing-masing hewan percobaan diberikan larutan glukosa $50 \%$. Kadar glukosa darah mencit dari masing-masing kelompok diukur kembali pada menit ke-60 $\left(\mathrm{T}_{1}\right), 90$ $\left(\mathrm{T}_{2}\right), 120\left(\mathrm{~T}_{3}\right)$ dan $150\left(\mathrm{~T}_{4}\right)$.

Pengukuran terhadap kadar glukosa darah mencit dilakukan menggunakan alat NESCO Multicheck glucose ${ }^{\circledR}$. 
Adapun cara kerja dari alat tersebut yaitu sebagai berikut.

1. Alat NESCO Multicheck glucose ${ }^{\circledR}$ dihidupkan, pasangkan strip test pada alat tersebut.

2. Ekor mencit dipotong dan didekatkan pada strip test sehingga darah yang keluar dari ekor mencit menempel pada strip test.

3. Tunggu 5 detik dan kadar glukosa darah akan terbaca pada layar monitor alat

\section{HASIL DAN PEMBAHASAN}

Fraksi air beras ketan hitam hasil ektraksi $1 \mathrm{Kg}$ beras ketan hitam, diperoleh sebanyak 2,1594 gram yang di gunakan sebagai bahan uji Antidiabetes pada mencit dengan metode toleransi glukosa test. Kadar glukosa rata-rata untuk setiap kelompok dapat dilihat pada Gambar 2 di bawah ini :

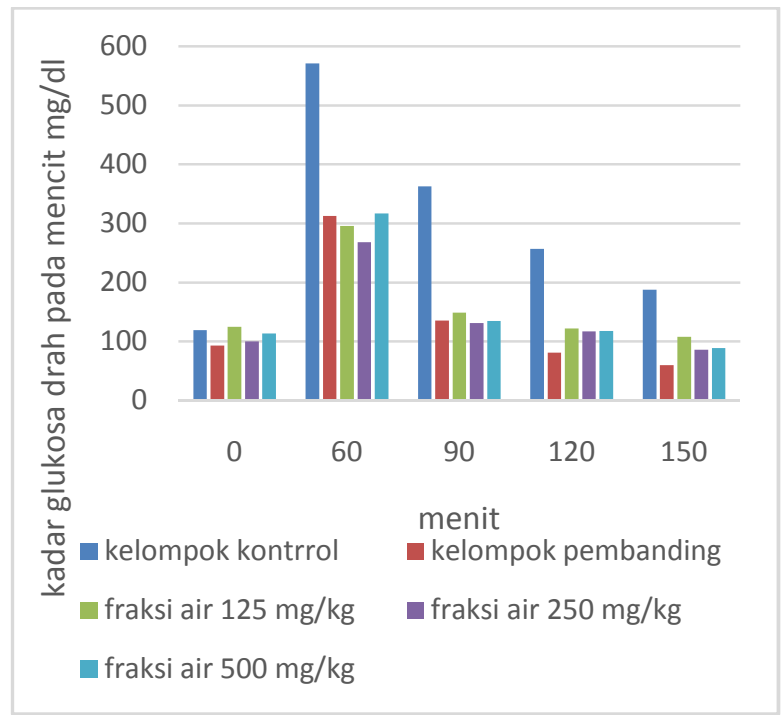

Gambar.2. Grafik kadar glukosa rata-rata fraksi air beras ketan hitam

Untuk mengetahui dosis fraksi air beras ketan hitam dan waktu perlakuan yang efektif dalam menurunkan kadar glukosa darah mencit, maka data hasil pengukuran dianalisis dengan menentukan persentase penurunan kadar glukosa darah mencit. Hasil analisis data diperoleh persentase penurunan kadar glukosa darah mencit pada masing-masing kelompok seperti pada tabel berikut :

Tabel 1. Persentase Penurunan Kadar Glukosa Darah Mencit setelah Pemberianfraksi air dan Glukosa 50\%

\begin{tabular}{|l|r|r|r|r|r|r|r|}
\hline \multirow{2}{*}{ Kelompok } & \multicolumn{3}{|c|}{$\begin{array}{c}\text { Kadar glukosa darah mencit rata- } \\
\text { rata (mg/dL) pada menit ke- }\end{array}$} & \multicolumn{2}{|c|}{$\begin{array}{c}\text { Persentase } \\
\text { penurunan kadar } \\
\text { glukosa darah }\end{array}$} \\
\cline { 2 - 8 } & 0 & 60 & 90 & 120 & 150 & PG1 & PG2 \\
\hline Kontrol & 119.5 & 571 & 363 & 257 & 188 & $36.43 \%$ & $54.99 \%$ \\
\hline pembanding & 93.5 & 313 & 135.5 & 81 & 60 & $56.71 \%$ & $74.12 \%$ \\
\hline $\begin{array}{l}\text { Dosis 125 } \\
\text { mg/kg }\end{array}$ & 125 & 296 & 149 & 122 & 108 & $49.66 \%$ & $58.78 \%$ \\
\hline $\begin{array}{l}\text { Dosis 250 } \\
\text { mg/kg }\end{array}$ & 100 & 268 & 131 & 117 & 86 & $51.12 \%$ & $56.34 \%$ \\
\hline $\begin{array}{l}\text { Dosis 500 } \\
\mathrm{mg} / \mathrm{kg}\end{array}$ & 114 & 317 & 134.5 & 118 & 89 & $57.57 \%$ & $62.78 \%$ \\
\hline
\end{tabular}

Berdasarkan Tabel 1 di atas dapat dilihat bahwa pada kelompok kontrol, persentase penurunan kadar glukosa darah mencit pada menit ke 90 (PG1) sebesar 36,43\%. Kemudian terjadi penurunan yang lebih besar pada menit ke 150 (PG2) yaitu sebesar 54,99\%. Pada waktu awal (T0) perbedaan kadar glukosa darah setiap kelompok tidak begitu signifikan, namun kadar glukosa tiap kelompok menjadi meningkat ketika di tambah dengan glukosa 50\%. Peningkatan kadar glukosa darah terjadi karena glukosa yan diberi secara oral akan diserap dari usus halus ke darah.

Pada kelompok pembanding persentase penurunan kadar glukosa darah mencit pada menit ke 90 (PG1) sebesar 56,71\%, kemudian pada menit ke-150 (PG2) $74,12 \%$.

Untuk dosis $125 \mathrm{mg} / \mathrm{kg}$ penurunan kadar glukosa darah pada menit ke 90 (PG1) yaitu $49,66 \%$ dan pada menit ke150 (PG2) yaitu $58,78 \%$. Untuk dosis $250 \mathrm{mg} / \mathrm{kg}$ penurunan kadar glukosa darah pada menit ke 90 (PG1) yaitu 51,12\% dan pada menit ke150 (PG2) yaitu 56,34\%. Kemudian untuk dosis $500 \mathrm{mg} / \mathrm{kg}$ penurunan kadar 
glukosa darah pada menit ke 90 (PG1) yaitu $57,57 \%$ dan pada menit ke150 (PG2) yaitu $62,78 \%$

Dari data hasil penelitian yang telah dilakukan terlihat bahwa beras ketan hitam mampu menurunkan kadar glukosa darah pada mencit. ekstrak berair beras ketan hitam tersebut diperkirakan mengandung zat aktif yaitu flavonoid, dimana flavonoid ini dapat digunakan untuk menurunkan kadar glukosa darah, yaitu dengan menghambat kerja enzim $\alpha$-glukokinase yang terdapat di usus halus. (Brahmachari,2011).

Enzim $\alpha$-glukokinase berfungsi untuk menghidrolisis oligosakarida menjadi monosakarida yang terdapat pada dinding usus halus. Penghambatan kerja enzim ini secara efektif dapat mengurangi pencernaan karbohidrat dalam bentuk molekul besar seperti polisakarida dan oligosakarida menjadi molekul yang lebih sederhana seperti glukosa, sehingga absorbsi glukosa dapat dikurangi. (Ratimanjari.2011)

Kadar glukosa darah mencit rata-rata pada kelompok uji yang diberi ekstrak beras ketan hitam fraksi berair berada di bawah rata-rata kelompok kontrol. Kadar glukosa darah mencit rata rata pada kelompok kontrol yaitu 299,7 mg/dL darah dan pada kelompok uji dengan dosis fraksi berair $125 \mathrm{mg} / \mathrm{kg} \mathrm{BB}, 250 \mathrm{mg} / \mathrm{kg}$ BB dan $500 \mathrm{mg} / \mathrm{kg}$ BB yaitu $160 \mathrm{mg} / \mathrm{dL}, 140,4$ $\mathrm{mg} / \mathrm{dL}, 154,5 \mathrm{mg} / \mathrm{dL}$.

Pada kelompok pembanding yang diberi suspensi glibenclamid yang di larutkan didalam NaCMC 10\% terjadi kenaikan rata-rata kadar glukosa darah pada menit ke-60 yaitu $313 \mathrm{mg} / \mathrm{dL}$, kemudian terjadi penurunan kadar glukosa darah pada menit ke 90, 120 dan 150 yaitu 135,5 mg/dL, 81 $\mathrm{mg} / \mathrm{dL}$ dan $60 \mathrm{mg} / \mathrm{dL}$.

Persentase penurunan kadar glukosa darah mencit dapat dilihat pada tabel 1 , dimana penurunan kadar glukosa darah yang paling tinggi terdapat pada fraksi berair $500 \mathrm{mg} / \mathrm{kg}$ yaitu $62,78 \%$.
Kelompok pembanding menggunakan glienclamid karena glibenclamid ini merupakan pengobatan secara modern untuk menurunkan kadar glukosa darah. Mekanisme kerja glibenclamid yaitu dengan merangsang sekresi hormon insulin (ratimanjari.2011). hormon insulin berfungsi untuk mengatur kadar glukosa dalam darah.

\section{SIMPULAN}

Dari penelitian dapat disimpulkan bahwa ekstrak berair dari beras ketan hitam dapat menurunkan kadar glukosa darah, dan penurunan tertinggi kadar glukosa darah terjadi pada dosis $500 \mathrm{mg} / \mathrm{kg} \mathrm{BB}$.

\section{DAFTAR PUSTAKA}

Agus, Ketut Adrianta. 2016. Identifikasi Senyawa Antosianin dan Metabolit Sekunder dari Ekstrak Etanol Beras Ketan Hitam (Oryza Sativa L) dalam Pemanfaatannya sebagai Alternative Pengobatan Demam Berdarah Dengue. Akademi Farmasi Saraswati Denpasar.

Amalia, Aini Nailufar. 2012. Kajian Karakteristik Ketan Hitam (oryza sativa glutinosa) pada Beberapa Jenis Pengemas Selama Penyimpanan. Jurnal Teknosains Pangan Vol 1

Brahmachari, Goutam. 2011. Bio-flavonoids with Promising Antidiabetic Potential: A Critical Survey. Research Signpost Opportunity, Challenge and Scope of Natural Products in Medicinal Chemistry, 2011: 187-212 ISBN: 978-81-308-0448-4

Devi, Dita Lestari, Diana S. Purwanto. 2013. Gambaran Kadar Glukosa Darah Puasa pada Mahasiswa Angkatan 2011 Fakultas Kedokteran Universitas Sam Ratulangi dengan Indeks Massa Tubuh 18,5-22,9 $\mathrm{kg} / \mathrm{m}^{2}$. Volume 1 Nomor 2 
Gustina. 2012. Aktivitas Ekstrak, Fraksi Pelarut, dan Senyawa Flavonoid Daun Sukun (Artocarpus Altilis) terhadap Enzim $\quad \alpha$-Glukosidase $\quad$ sebagai Antidiabetes. Skripsi : FMIPA IPB, Bogor

Kurnia, Shara Trisnawati dan Soedijino Setyorogo. 2013. Faktor Risiko Kejadian Diabetes Melitus Tipe II di Puskesmas Kecamatan Cengkareng Jakarta Barat tahun 2012. Jurnal Ilmiah Kesehatan 5(1).

Ikatan Dokter Anak Indonesia. 2015. Konsensus Nasional Pengelolaan Diabetes Mellitus Tipe 2. Jakarta: UKK Endokrinologi Anak dan Remaja.

Kusuma, Theresia S. 1988. Kimia dan Lingkungan. Jurusan Kimia FMIPA UNAND, Padang.

Mitra, Analava. 2008. Diabetes and Stress: A Revew. Ethno-Med., 2(2): 131-135.

Mustofa, Ari Yuniastuti, Aditya Marianti. 2012. Efek Pemberian Jus Lidah Buaya Terhadap Kadar Glukosa Darah Tikus Putih. ISSN 2252-6277

Neal Nj. 2002. Medical Pharmacology a Glance. New York : Blackwell Science.

Rahayuningsih, Nur dan Shinta Amalia. 2014. Uji Aktivitas Antidiabetes Ekstrak Etanol Daun Popohan (pilea trinervia wight) pada Mencit Putih Jantan Galur Swiss Webster

Rahayuningsih, Nur dan Shinta Amelia. 2015. Uji Aktivitas Antidiabetes Infusa Daun Pohpohan (pilea trinervia wight) pada Mencit Putih Jantan Galur Swiss Webster.

Ratimanjari, D.A. 2011. Pengaruh Pemberian Infusa Herba Sambiloto (andrographis paniculata nees) terhadap Glibenklamid dalam Menurunkan Kadar Glukosa Darah Tikus Putih Jantan yang Dibuat Diabetes. Fakultas Matematika dan Ilmu Pengetahuan Alam, Universitas Indonesia.

Rukmini. 2003. Komposisi Gizi Beberapa Makanan Fermentasi Tradisional Yogyakarta

Soemartono. 1980. Bercocok Tanam Padi. Yasaguna. Jakarta) dalam Hanum, Tirza. 2000. Ekstraksi dan Stabilitas Zat Pewarna dari Katul Beras Ketan Hitam. Buletin Teknologi dan Industri Pangan, Vol.XI, No.1,Tahun 2000

Sower, J.R., Epstein, M., and Frohlich, E.D,2001, Hypertention and Cardiovascular disease: an Update Hypertention, 37,1053-1105

Sustrani L,et al. 2006. Diabetes. Jakarta : Gramedia Utama

Widowati. Wahyu. Potensi Antioksidan sebagai Antidiabetes. Universitas Kristen Maranatha. Bandung

Yuliana Elin, Andradjati Retnosari, dkk. 2009. ISO Farmakoterapi 2. ISFI,Jakarta 